\title{
I(৫)
}

\begin{tabular}{||l||c||c||}
\hline \hline Received 14.12.2021 & & JOTS \\
$6 / 1$ \\
Accepted 28.12.2021 & Review & $2022: 209-213$ \\
\hline \hline Published 01.01.2022 & & \\
\hline
\end{tabular}

\section{Taşağıl, A. Uygurlar -840'tan Önce-, İstanbul: Bilge Kültür Sanat Yayınlar1, 2021, ss. 192. ISBN: 978-625-7201-22-3}

\author{
Cem BuLAM ${ }^{*}$ \\ (Malatya/Turkey) \\ E-mail: cem_bulam_44@hotmail.com
}

Orta Asya Türk tarihi alanında yaptığı çalışmalarla Eski Türk dili tarihi bilim dalına ve genel anlamda tarih alanına önemli katkılar sunmuş olan Prof. Dr. Ahmet Taşağıl, Uygurlar -840'tan önce- başlıklı eseriyle bu katkılara bir yenisini daha eklemiştir. $\mathrm{Bu}$ yazıda, eserle ilgili ana hatlarıyla genel bir tanıtma amaçlanmaktadır.

Eserin temelinde Uygurların 840'tan önceki tarihî süreci yer almaktadır. Türkçe kaynaklarda adlarına ilk olarak Orhun yazıtlarında rastlanılan Uygurlar, bugün de varlığını devam ettiren Türk boylarındandır. Tarih sahnesinde onlar da bugünkü Moğol bozkırlarında Hunlar ve Göktürkler gibi devlet kurmuşlardır.

Eserde, Uygurların tarihî derinliklerden bugüne kadar farklı alan ve zamanlarda yaşadıkları kırılma anları, bu anların neticesinde başlarından geçen serüvenler kronolojik sırayla birbiriyle bağlantılı olarak anlatılır.

Eser, ön sözden sonra yedi ana ve otuz iki alt başlık ile bibliyografya, dizin ve ekler kısmindan meydana gelmiştir.

Eserin önsözünde yazar amaçlarını belirtmiş ve yapılan çalışmanın hangi dönemi ve hangi alanları kapsadığından bahseder.

ORCID ID: 0000-0001-6194-4505. 
Eserin Ötüken Uygurlarına Genel Bakış ana başllğ̆ altında (s. 11-23) Ötüken Uygurlarının boylarına, genel tarihine, devlet kurma şekillerine, devlet hanedanına ait bilgiler mevcuttur.

Eserin ikinci ana başlı̆̆ı olan Bağımsızlık Öncesi Uygurlar bölümünde (s. 24) Uygurların bağımsız devlet kurmadan önce nerelerde ve hangi şekilde yaşadığ hakkında bilgiler aktarılmaktadır. Coğrafî olarak nerelerde kabile ve boy halinde yaşadıkları bilgileri de paylaşılır. Birinci alt başlık olarak Uygurların Kökeni kısmında Uygurların hangi boylardan ve etnik yapılardan meydana geldiğini ve günümüze kadar nasıl bir gelişme gösterdikleri hakkında önemli bilgiler aktarılmıştır. İkinci alt başlıkta, bağımsızlıktan önceki siyasî ve kültürel faaliyetlerinin neler olduğundan bahsedilmiştir. Komşu kavimlerle ve boylarla olan ilişkiler, kendi içerisinde yaşanan kültürel gelişmeler ve daha birçok bilgiyi görmek mümkündür.

Eserin üçüncü ana başlığı Uygur Kağanliğının Kuruluşu ve Yükselişi (s. 34-35) Gök Türk Kağanlığına son verilmesinin ardından Kutluk Bilge Kül'ün bağımsızlığını ilan ettiği ve ardından arkasında güç olarak gördüğü Dokuz Oğuzlar ve Uygur Kabileleri arasındaki siyasî ilişkiler ve ortak kültür öğeleri okura sunulup, Tokuz Oğuzlar alt başlı̆̆ında ise neden Tokuz Oğuz denildiği, bu dokuz boyun hangileri olduğu ve Uygurlarla ilişkilerinin nereden geldiği hakkında bilgiler verilir. Uygur Kağanlığının en etkili hükümdarı Bayan Çor'un anlatıldığı alt başlık ise Bayan Çor Kağan ve Genişleme Siyaseti (s. 39) olarak okuyucu karşısına çıkıyor. Uygur Kağanlığı'nın onun döneminde nasıl geliştiği, nerelere sefer düzenlediği ve hangi topluluklarla ikili ilişkiler yürütüldüğü, Çin ile komşuluk ilişkilerinin nasıl olduğu anlatılır. Çin'deki iç isyanlarda Uygurların nasıl roller üstlendiği, komşu çin'e askerî yardımların ne amaçla ve neden yapıldığı, bu yardımların ne gibi ödülleri olduğu da yine bu başlıklar ile gözler önüne serilir. Bu başlığı Uygur Kağanlığına en parlak günlerini yaşatan Bayan Çor Kağan'ın ölümünün anlatıldığı Bayan Çor Kağan’n ölümü başlığı (s. 54-55) takip eder. Bu başlıkta ölümünden sonra kağanın yerine kimin geçtiği ve gelen kağanın nasıl bir devlet stratejisi izlediği, cenaze töreninde neler yaşandığı, hangi devletlerin ve kabilelerin bu cenaze törenine katıldığ ile ilgili bilgilere yer verilir. Çalışmanın Yazıtlarda Bayan Çor Kağan Anlatımı alt başlı̆̆ında (s. 56), 12 yıl süreyle Uygur Kağanlığı'nın başında kalan ve bu süre içinde ülkesi ve milleti için çok yararlı işler yapan Bayan Çor'un faaliyetlerini anlattı̆̆ üç yazıtı sırasıyla 


\section{ग(৫)}

verilmiştir. Bunlardan ilki Tes Yazıtı'dır. Yazıtın nerede bulunduğu ve içeriğinin nelerden ibaret olduğu, hangi yılda yazıldığı ve yazıtta kimlerin adlarının geçtiği bilgilerine ulaşılmaktadır. İkinci yazıt Taryat Yazıtı'nda ise bilgilerin önceki yazıta göre daha detaylı olarak anlatıldığından ve Uygurların kendilerini, Gök Türklerin devamı olarak mı gördüklerinden bahsedilmiştir. Üçüncü yazıt olan Şine Us Yazıtı'nın ise en teferruatlı bilgi içeren yazıt olduğu, bulunduğu yer ve taş üzerinde anlatılanların içerikleri hakkında bilgiler verilmiştir. Eserin alt başlıklarından Bayan Çor Kağan Zamanında Bazı Türk Boyları bölümünde (s. 67), Basmıllar, Çikler, Karluklar boylarının Uygurlarla olan siyasi ve kültürel ilişkileri, askeri alandaki iş birlikleri ve izledikleri politikalar Eserin ana başlıklarından birisi olan Böğü Kağan Devri başlığında (s. 84-85) ise tahta çıan yeni kağanın Çin ile ilişkilerinden söz edilir. Çin'e yapılan askerî yardımların artarak devam ettiği ve ikili ilişkilerin o dönem için yolunda olduğu bilgisi verilmiştir. Mani Dinine Giriş adlı başlıkta (s. 92-103) ise Uygurların neden Mani dinine geçtiklerini, bu dine kimin vasıtasıyla ilgi duydukları ve bu dinin kabul edilmesiyle bozkır kültüründen ne derece uzaklaştıkları anlatılır. Mani dininin etkisine giren Uygurlarda kültürel, askerî ve sosyal alanda ne gibi değişimler ve olumsuzluk olduğu açıkça ifade edilmiştir. Uygurlara ticaret yapmayı öğreten Soğdlular ile ilerleyen süreçte de ilişkilerin olumlu yönde olduğu bilgisi verilmiştir. Kağana Muhalefet ve İhtilal alt başlı̆̆ında (s. 105-107) Bögü Kağan'a kimlerin neden ihtilal yaptığı ve bu ihtilal ile Uygurlarda ne gibi değişlikler olduğu, Uygurlarda hangi komutanların Mani dininin etkisi altında olmaktan hoşnut olmadığı gibi soruların cevapları verilir.

Uygurların Duraklama Devri adını taşıyan beşinci ana başlıkta (s. 108) Tun Baga Tarkan'ın başa geçmesi ve Çin ile ikili ilişkilerin bozulması ve aralarında yaşanan bazı olumsuzluklar anlatılır. Çin'de Uygur Kolonisinin Kapatılması alt başlı̆̆ında (s. 109-113) Uygurların Çin içlerinde yaşayan kolonisinin Çin imparatorunu ikna ettikten sonra nasıl ve neden dağıtıldığı, orada yaşayan Uygurların nerelere göç etmek zorunda kaldığı ve Çin yönetiminin neden Uygurlara karşı Dokuz Oğuz boylarını tuttuğu bilgilerine ulaşılır. Tibetlilerin Güç Olarak Ortaya Çıkması alt başlı̆̆ında (s. 114-116) Tibetlilerle girdiği savaşı kaybeden Uygurların yaşadığı olaylar anlatılmıştır. Uygurların yağma ve baskılarından bunalan birçok yöre halkının Uygurlara karşı nasıl bir tavır takındığı, kimlerle iş birliği yaptığı açıklanır. Devletin Yeniden Güçlenmesi (s. 117- 


\section{ग(৫)}

126) alt başlığında bir süredir güç kaybeden Uygurların, Kutlug Kağan ile birlikte yeniden otoriteyi eline aldığından bahsedilmektedir. Bu güçlerin elde edildiği dönemde Tibetliler ve Çinliler ile olan ilişkiler anlatılır.

Yıkılışa Giden Siyasi Karışılklklar (s. 127) ana başlığında ise Alp Bilge Kağan'ın ölümünün ardından yerine gelen Alp Küçlüg Bilge Kağan'dan başlayarak Çin ile ikili ilişkiler, devlet yönetimi ve askeri stratejiler gibi birçok alanda karışıklık meydana geldiği anlatılır. Uygurların bu dönemde kendi içlerinde ihtilaller yaşadığı, toplumsal sıkıntıların ve felaketlerin de eksilmediği bilgileri paylaşılır. Çin'in entrikaları ve soğuk harp taktiklerinin içeriden zayıflattığı Uygurların 839 kışının sert geçmesinden kaynaklı olarak hayvanlarının telef olmasının da siyasi ve toplumsal buhranı arttırdığ ve devletin kan kaybetmesine neden olduğu anlatılır. Uygur komutanlarından Külüg Baga'nın Kırgızların da yardımıyla Uygur başkentini bastığı ve kağanlık otağı dâhil bütün değerli varlıkların Kırgızların eline geçtiği bilgisi verilmiştir. Kansu Uygurları alt başlığında (s. 135) Orhun bölgesinde tutunamayan Uygurların farklı kollara ayrılmaları sonucunda son kalan grubun Kansu bölgesine gittiği ve adlarının buradan geldiği bilgisi aktarılır. Ayrıca bugün Sarı Uygur adıyla bilindikleri de aktarılmıştır. Beşbalık Uygurları alt başlı̆̆ında (s. 135) Orhun bölgesinde tutunamayan Uygurların bir kısmının da Beşbalık bölgesine gittiği anlatılır. Manihaizm dininin buradan Çin'e yayıldığı daha sonra ise Beşbalık Uygurları'nda Budizm'in Manihaizm'in yerini aldığı anlatılmaktadır. Orta Asya'da varlıklarını sürekli hissettirdikleri aktarılmıştır.

Uygurların Kültürel Durumu Hakkında ana başlığının (s. 137) Uygur Devletine Genel Bir Bakış alt başlığında (s. 137) Uygur Kağanlığı ve Uygurlar hakkında -dinî, sosyolojik, kültürel, askerî güç ve devlet kademeleri ile ilgili- tanıtıcı, açıklayıcı genel bilgilere yer verilir. Uygur Kültürü Hakkında Birkaç Söz alt başlı̆̆ında (s. 142143) ise Uygurların kültürel özellikleri, etkilendikleri kültürler ile kendi özgün kültürlerinin teşekkülünde rol oynayan komşu devlet ve kabileler gibi konulara cevaplar bulunmaktadır. Uygurlarda Mimari Karakteristik alt başlığında (s. 144148) Uygurların yerleşik hayata geçmesiyle birlikte inşa ettikleri şehirler, tapınaklar, mağara tapınakları ve anıt mezar motifleri üzerinde durulmuş ve hangi özgün, karakteristik eserler verildiği, bu eserlere etki eden kültürel ve dini aktarımların neler olduğu bilgileri paylaşılır. 


\section{J(৫)}

Eserin sonunda Bibliyografya (s. 149-152), Dizin (s. 153-166) ve Ekler (s. 167181) başliğına yer verilmiş, Ekler'de Chiou T'ang Shu 195A-B ve Hsin T'ang Shu 217A-B Çin yıllıklarının fotoğrafları okuyucuyla görsel olarak paylaşılır.

Büyük zaman ve emek ürünü olan kitap bizlere Uygur tarihi hakkında teferruatlı bilgiler sunmaktadır. 